\title{
Air-sea exchange of gaseous mercury in the East China Sea ${ }^{\text {th }}$
}

\author{
Chunjie Wang ${ }^{\text {a, b }}$, Zhijia $\mathrm{Ci}^{\text {a, }}{ }^{*}$, Zhangwei Wang ${ }^{\text {a }}$, Xiaoshan Zhang ${ }^{\text {a }}$ \\ ${ }^{a}$ Research Center for Eco-Environmental Sciences, Chinese Academy of Sciences, No. 18 Shuangqing Road, Beijing 100085, China \\ ${ }^{\mathrm{b}}$ Graduate School of Chinese Academy of Sciences, Beijing 100049, China
}

\section{A R T I C L E I N F O}

\section{Article history:}

Received 14 January 2016

Received in revised form 2 March 2016

Accepted 4 March 2016

Available online 11 March 2016

\section{Keywords:}

Gaseous elemental mercury

Dissolved gaseous mercury

Air-sea exchange

East China Sea

\begin{abstract}
A B S T R A C T
Two oceanographic cruises were carried out in the East China Sea (ECS) during the summer and fall of 2013. The main objectives of this study are to identify the spatial-temporal distributions of gaseous elemental mercury (GEM) in air and dissolved gaseous mercury (DGM) in surface seawater, and then to estimate the $\mathrm{Hg}^{0}$ flux. The GEM concentration was lower in summer $\left(1.61 \pm 0.32 \mathrm{ng} \mathrm{m}^{-3}\right)$ than in fall $\left(2.20 \pm 0.58 \mathrm{ng} \mathrm{m}^{-3}\right)$. The back-trajectory analysis revealed that the air masses with high GEM levels during fall largely originated from the land, while the air masses with low GEM levels during summer primarily originated from ocean. The spatial distribution patterns of total $\mathrm{Hg}(\mathrm{THg})$, fluorescence, and turbidity were consistent with the pattern of DGM with high levels in the nearshore area and low levels in the open sea. Additionally, the levels of percentage of DGM to THg (\%DGM) were higher in the open sea than in the nearshore area, which was consistent with the previous studies. The THg concentration in fall was higher $\left(1.47 \pm 0.51 \mathrm{ng} \mathrm{l}^{-1}\right)$ than those of other open oceans. The DGM concentration $\left(60.1 \pm 17.6 \mathrm{pg} \mathrm{l}^{-1}\right)$ and $\mathrm{Hg}^{0}$ flux $\left(4.6 \pm 3.6 \mathrm{ng} \mathrm{m}^{-2} \mathrm{~h}^{-1}\right)$ in summer were higher than those in fall (DGM: $49.6 \pm 12.5 \mathrm{pg} \mathrm{l}^{-1}$ and $\mathrm{Hg}^{0}$ flux: $3.6 \pm 2.8 \mathrm{ng} \mathrm{m}^{-2} \mathrm{~h}^{-1}$ ). The emission flux of $\mathrm{Hg}^{0}$ from the ECS was estimated to be 27.6 tons $\mathrm{yr}^{-1}$, accounting for $\sim 0.98 \%$ of the global $\mathrm{Hg}$ oceanic evasion though the ECS only accounts for $\sim 0.21 \%$ of global ocean area, indicating that the ECS plays an important role in the oceanic Hg cycle.
\end{abstract}

(c) 2016 Elsevier Ltd. All rights reserved.

\section{Introduction}

Mercury $(\mathrm{Hg})$ is a trace element distributed throughout the earth's atmosphere, biosphere, and geosphere (Choy et al., 2009; Schroeder and Munthe, 1998). Gaseous elemental mercury (GEM or $\mathrm{Hg}^{0}$ ) is very stable with a residence time between 0.5 and 1 year in the atmosphere (Radke et al., 2007; Selin et al., 2007), which can be transported for a long distance. $\mathrm{Hg}$ enters the atmosphere through both anthropogenic and natural pathways (Pacyna et al., 2010; UNEP, 2013), with direct anthropogenic emissions representing approximately 30\% of the annual emissions of $\mathrm{Hg}$ to air (Mason and Sheu, 2002; UNEP, 2013). Another 10\% comes from natural geological sources, and the rest $60 \%$ is from 're-emissions' of previously released $\mathrm{Hg}$ that has build up over decades and centuries in surface soils and oceans (UNEP, 2013). Previous studies have shown that oceans and seas receive about $60 \%$ of the global atmospheric deposition (Soerensen et al., 2010b; Strode et al., 2007).

\footnotetext{
* This paper has been recommended for acceptance by B. Nowack.

* Corresponding author.

E-mail address: zjci@rcees.ac.cn (Z. Ci).
}

The oceans and seas are both source and sink of atmospheric $\mathrm{Hg}$ and play a vital role in the global Hg cycle (Soerensen et al., 2013; Strode et al., 2007).

Generally, dissolved gaseous mercury (DGM) in seawater includes both $\mathrm{Hg}^{0}$ and dimethylmercury, but little dimethylmercury (generally $<5 \%$ ) can be found in the surface seawater (Bowman et al., 2015; Hammerschmidt and Bowman, 2012). DGM is only a small fraction of total $\mathrm{Hg}$ ( $\mathrm{THg}$ ) in seawater, but plays an important role in the oceanic $\mathrm{Hg}$ cycle (Fu et al., 2010). DGM evasion from surface seawater not only reduces the $\mathrm{Hg}$ burden in the waters and limits the methylmercury production, but also contributes to the redistribution of $\mathrm{Hg}$ on both regional and global scale (Mason and Sheu, 2002; Sunderland and Mason, 2007). It was estimated that more than $80 \%$ of the $\mathrm{Hg}$ that previously deposited to oceans reemited to the atmosphere as $\mathrm{Hg}^{0}$ (Soerensen et al., 2010b; Strode et al., 2007). Thus the air-sea exchange of $\mathrm{Hg}^{0}$ is a critical part of the oceanic $\mathrm{Hg}$ cycle, which is one of the processes in its global biogeochemical cycle (Sprovieri et al., 2010; Strode et al., 2007, 2010).

China is the largest contributor to global atmospheric $\mathrm{Hg}$ (Pacyna et al., 2010; UNEP, 2013). Anthropogenic Hg emissions in 
China are likely to further increase with the expansion of artisanal and small-scale gold mining, coal combustion, and nonferrous production (UNEP, 2013; Zhang et al., 2015a), which may cause Hg pollution in the surrounding regions, even on a global scale (Obrist et al., 2008; Travnikov, 2005). Previous studies conducted in the Bohai Sea, the Yellow Sea, and the South China Sea showed that the THg concentrations in seawater and GEM concentrations in the atmosphere were higher than those of other remote marine environments, which may be linked to the riverine discharge (Ci et al., 2014; Han et al., 2004; Zhang et al., 2015b) and export of $\mathrm{Hg}$ enriched air masses from East Asia (Ci et al., 2011a,b,d; 2015; Fu et al., 2010; Tseng et al., 2012, 2013; Wang et al., 2016a,b). During the past decade, numerous studies with respect to the air-sea exchange of $\mathrm{Hg}^{0}$ have been carried out in other waters, including marginal seas (e.g., the Yellow Sea, the South China Sea, and the Mediterranean Sea) and oceans (e.g., the Atlantic Ocean and the Pacific Ocean) (see Table 1). However, there is no documentation on the air-sea exchange of $\mathrm{Hg}^{0}$ in the East China Sea (ECS), and only a few studies regarding the speciated atmospheric $\mathrm{Hg}$ and total $\mathrm{Hg}$ in sediments have been reported (Chand et al., 2008; Duan et al., 2015; Fang and Chen, 2010; Shi et al., 2005; Wang et al.. 2016a,b). The main objectives of this study are to investigate the spatialtemporal distributions of GEM and DGM, estimate the $\mathrm{Hg}^{0}$ flux in the ECS, and examine associated environmental drivers of changing DGM concentration and $\mathrm{Hg}^{0}$ flux.

\section{Experiments}

\subsection{Study area and sampling stations}

The ECS is a semi-enclosed marginal sea and located in the downwind of East Asia (Fig. 1). It is connected with the Yellow Sea to the north, the Pacific Ocean to the east, and the South China Sea to the south. It is the link for material and energy exchange between the Yellow Sea and the West Pacific Ocean. Moreover, a number of rivers (including the Yangtze, Qiantang, Oujiang, and Minjiang Rivers, etc.) carrying large land-sourced materials enter the ECS. The surrounding areas of the ECS are developing or developed countries and regions, including China, Korean Peninsula, Japan, and Taiwan Island. Additionally, there are many developed cities along the coast of the ECS (Fig. 1), resulting in a large number of factories in this area. The ECS is then a potentially important receptor for $\mathrm{Hg}$ emissions from East Asia. The hydrographic characteristics of this region are greatly affected by the water masses, including the nutrient rich and low salinity Changjiang (Yangtze) Diluted Water (CDW) and the Zhejiang-Fujian Coastal Current (ZFCC) along the Chinese coast (Chen et al., 2016). Two open cruises were organized by the Institute of Oceanology, Chinese Academy of Sciences (IOCAS) and conducted from 21 June to 19 July 2013 (summer) and 27 October to 18 November 2013 (fall), respectively. The sampling stations are located in the inner and middle continental shelf of the ECS (Fig. 1).

\subsection{Sampling and analytical methods}

\subsubsection{Measurement of GEM}

Atmospheric GEM was continuously measured using an automatic dual channel, single amalgamation cold vapor atomic fluorescence analyzer (Model 2537B, Tekran ${ }^{\circledR}$, Inc., Toronto, Canada) with a soda-lime trap and a Teflon filter $(0.2 \mu \mathrm{m}$ pore size, $47 \mathrm{~mm}$ diameter) just upstream, which has been reported in our previous study (Wang et al., 2016a,b). In this study, the sampling interval was

Table 1

GEM and DGM concentrations and air-sea exchange fluxes of $\mathrm{Hg}^{\mathrm{0}}$ in marginal seas (including the East China Sea) and oceans.

\begin{tabular}{|c|c|c|c|c|c|c|c|c|c|}
\hline Location & Type & Sampling time & Longitude & Latitude & $\mathrm{DGM}\left(\mathrm{pg} \mathrm{l}^{-1}\right)$ & $\begin{array}{l}\text { GEM } \\
\left(\mathrm{ng} \mathrm{m}^{-3}\right)\end{array}$ & $\begin{array}{l}\text { Wind speed } \\
\mathrm{u}_{10}\left(\mathrm{~m} \mathrm{~s}^{-1}\right)\end{array}$ & $\begin{array}{l}\text { Flux } \\
\left(\mathrm{ng} \mathrm{m}^{-2} \mathrm{~h}^{-1}\right)\end{array}$ & Reference \\
\hline \multirow[t]{2}{*}{ East China Sea } & Summer & 2013 & $120^{\circ} \mathrm{E}-128^{\circ} \mathrm{E}$ & $25^{\circ} \mathrm{N}-31^{\circ} \mathrm{N}$ & $61.2 \pm 19.7$ & $1.61 \pm 0.32$ & $4.9 \pm 1.8$ & $4.6 \pm 3.4$ & This work \\
\hline & Fall & 2013 & $120^{\circ} \mathrm{E}-128^{\circ} \mathrm{E}$ & $25^{\circ} \mathrm{N}-31^{\circ} \mathrm{N}$ & $52.4 \pm 17.6$ & $2.20 \pm 0.58$ & $5.1 \pm 1.9$ & $3.6 \pm 2.8$ & This work \\
\hline \multirow[t]{2}{*}{$\mathrm{CST}^{\mathrm{a}}$} & Summer & October 2008 & $122.68^{\circ} \mathrm{E}$ & $37.38^{\circ} \mathrm{N}$ & $69.0 \pm 23.3$ & $1.98 \pm 0.97$ & $1.5 \pm 1.0$ & $0.9 \pm 1.4$ & Ci et al., 2011a \\
\hline & Fall & August 2009 & $122.68^{\circ} \mathrm{E}$ & $37.38^{\circ} \mathrm{N}$ & $27.0 \pm 16.4$ & $2.36 \pm 0.66$ & $3.8 \pm 1.9$ & $0.9 \pm 1.8$ & Ci et al., 2011a \\
\hline \multirow[t]{2}{*}{ Yellow Sea } & Summer & 9-18 July 2010 & $119^{\circ} \mathrm{E}-126^{\circ} \mathrm{E}$ & $31^{\circ} \mathrm{N}-40^{\circ} \mathrm{N}$ & $63.9 \pm 13.7$ & $2.61 \pm 0.50$ & $9.6 \pm 3.7$ & $18.3 \pm 11.8$ & Ci et al., 2011d \\
\hline & Fall & $\begin{array}{l}2-17 \text { November } \\
2012\end{array}$ & $119^{\circ} \mathrm{E}-126^{\circ} \mathrm{E}$ & $31^{\circ} \mathrm{N}-40^{\circ} \mathrm{N}$ & $28.2 \pm 9.0$ & $1.81 \pm 0.45$ & $6.7 \pm 3.8$ & $2.5 \pm 2.1$ & Ci et al., 2015 \\
\hline South China Sea & Summer & $\begin{array}{l}10-28 \text { August } \\
2010\end{array}$ & $109^{\circ} \mathrm{E}-121^{\circ} \mathrm{E}$ & $16^{\circ} \mathrm{N}-24^{\circ} \mathrm{N}$ & $36.5 \pm 14.9$ & $2.62 \pm 1.13$ & $6.7 \pm 2.7$ & $4.5 \pm 3.4$ & Fu et al., 2010 \\
\hline \multirow[t]{2}{*}{ SEATS $^{b}$} & Summer & 2003 to 2007 & $116^{\circ} \mathrm{E}$ & $18^{\circ} \mathrm{N}$ & $32.0 \pm 8.0$ & $2.8 \pm 0.4$ & $5.5 \pm 0.2$ & $4.8 \pm 1.0$ & $\begin{array}{l}\text { Tseng et al., 2012, } \\
2013\end{array}$ \\
\hline & Fall & 2003 to 2007 & $116^{\circ} \mathrm{E}$ & $18^{\circ} \mathrm{N}$ & $24.0 \pm 6.0$ & $3.8 \pm 0.3$ & $8.6 \pm 1.5$ & $6.1 \pm 1.8$ & $\begin{array}{l}\text { Tseng et al., 2012, } \\
2013\end{array}$ \\
\hline Tokyo Bay & Fall/Winter & 2003 to 2005 & $139^{\circ} \mathrm{E}-141^{\circ} \mathrm{E}$ & $35^{\circ} \mathrm{N}-36^{\circ} \mathrm{N}$ & $52.0 \pm 26.0$ & $1.9 \pm 0.6$ & $5.3 \pm 2.3$ & $5.8 \pm 5.0$ & $\begin{array}{l}\text { Narukawa et al., } \\
2006\end{array}$ \\
\hline \multirow[t]{2}{*}{ Minamata Bay } & Summer & 2012 to 2013 & $130^{\circ} \mathrm{E}-130.5^{\circ} \mathrm{E}$ & $32^{\circ} \mathrm{N}-32.5^{\circ} \mathrm{N}$ & $218 \pm 84$ & $1.77 \pm 0.19$ & $1.6 \pm 0.7$ & $4.1 \pm 2.6$ & $\begin{array}{l}\text { Marumoto and Imai, } \\
2015\end{array}$ \\
\hline & Fall & 2012 to 2013 & $130^{\circ} \mathrm{E}-130.5^{\circ} \mathrm{E}$ & $32^{\circ} \mathrm{N}-32.5^{\circ} \mathrm{N}$ & $88 \pm 23$ & $2.15 \pm 0.21$ & $4.8 \pm 2.3$ & $9.6 \pm 8.8$ & $\begin{array}{l}\text { Marumoto and Imai, } \\
2015\end{array}$ \\
\hline \multirow[t]{4}{*}{ Mediterranean Sea } & Summer & 17-23 July 2000 & $17^{\circ} \mathrm{E}-28^{\circ} \mathrm{E}$ & $32^{\circ} \mathrm{N}-36^{\circ} \mathrm{N}$ & $34.9 \pm 9.8$ & $1.80 \pm 0.37$ & $7.5 \pm 2.4$ & $7.9 \pm 4.5$ & Gårdfeldt et al., 2003 \\
\hline & Summer & August 2003 & $8^{\circ} \mathrm{W}-24^{\circ} \mathrm{E}$ & $33^{\circ} \mathrm{N}-45^{\circ} \mathrm{N}$ & 38.0 & 1.76 & 5.9 & 4.5 & Andersson et al., 2007 \\
\hline & Fall & 2004 & $8^{\circ} \mathrm{W}-24^{\circ} \mathrm{E}$ & $33^{\circ} \mathrm{N}-48^{\circ} \mathrm{N}$ & 38.0 & 1.66 & 7.0 & 4.9 & Andersson et al., 2007 \\
\hline & Summer & 2010 & $11^{\circ} \mathrm{E}-29^{\circ} \mathrm{E}$ & $33^{\circ} \mathrm{N}-40^{\circ} \mathrm{N}$ & $33.6 \pm 23.3$ & $1.55 \pm 0.15$ & $5.1 \pm 2.7$ & $2.2 \pm 1.5$ & Fantozzi et al., 2013 \\
\hline \multirow[t]{2}{*}{ Baltic Sea } & Summer & 3-13 July 1997 & $13^{\circ} \mathrm{E}-22^{\circ} \mathrm{E}$ & $54^{\circ} \mathrm{N}-57^{\circ} \mathrm{N}$ & 17.6 & 1.70 & 6.2 & 1.6 & Wängberg et al., 2001 \\
\hline & Year & 2006 & $10^{\circ} \mathrm{E}-22^{\circ} \mathrm{E}$ & $54^{\circ} \mathrm{N}-60^{\circ} \mathrm{N}$ & “10-32 & $1.0-3.0$ & $6.7-9.4$ & 2.08 & $\begin{array}{l}\text { Kuss and Schneider, } \\
2007\end{array}$ \\
\hline \multirow[t]{2}{*}{ Atlantic Ocean } & Summer & 7-11 July 2005 & $5^{\circ} \mathrm{E}-40^{\circ} \mathrm{W}$ & $60^{\circ} \mathrm{N}$ & $11.6 \pm 2.0$ & $1.7 \pm 0.1$ & 9.5 & $0.4 \pm 0.4$ & Andersson et al., 2011 \\
\hline & Fall/spring & 2008 to 2009 & $70^{\circ} \mathrm{W}-10^{\circ} \mathrm{E}$ & $50^{\circ} \mathrm{S}-50^{\circ} \mathrm{N}$ & $3-27$ & $<2.0$ & $<10.0$ & Mean $<2.0$ & Kuss et al., 2011 \\
\hline West Atlantic Ocean & Summer/fall & 2008 to 2010 & $75^{\circ} \mathrm{W}-60^{\circ} \mathrm{W}$ & $25^{\circ} \mathrm{N}-45^{\circ} \mathrm{N}$ & $\begin{array}{l}18.0 \pm 4.8 \\
-39.2 \pm 6.4\end{array}$ & $\begin{array}{l}1.4 \pm 0.1 \\
-1.5 \pm 0.1\end{array}$ & $\begin{array}{l}5.1 \pm 2.3 \\
-7.4 \pm 3.3\end{array}$ & $\begin{array}{l}2.1 \pm 0.1 \\
-6.8 \pm 5.1\end{array}$ & Soerensen et al., 2013 \\
\hline South Pacific Ocean & Fall & 1-24 October 2011 & $180^{\circ} \mathrm{E}-150^{\circ} \mathrm{W}$ & $1^{\circ} \mathrm{N}-15^{\circ} \mathrm{N}$ & $9.4 \pm 2.7$ & $1.15 \pm 0.05$ & $5.6 \pm 1.7$ & $0.8 \pm 0.4$ & Soerensen et al., 2014 \\
\hline
\end{tabular}

a CST denotes Chengshantou (a coastal site in Shandong Province, China).

b SEATS denotes Southeast Asian Time-series Study (a station in the northern South China Sea). 


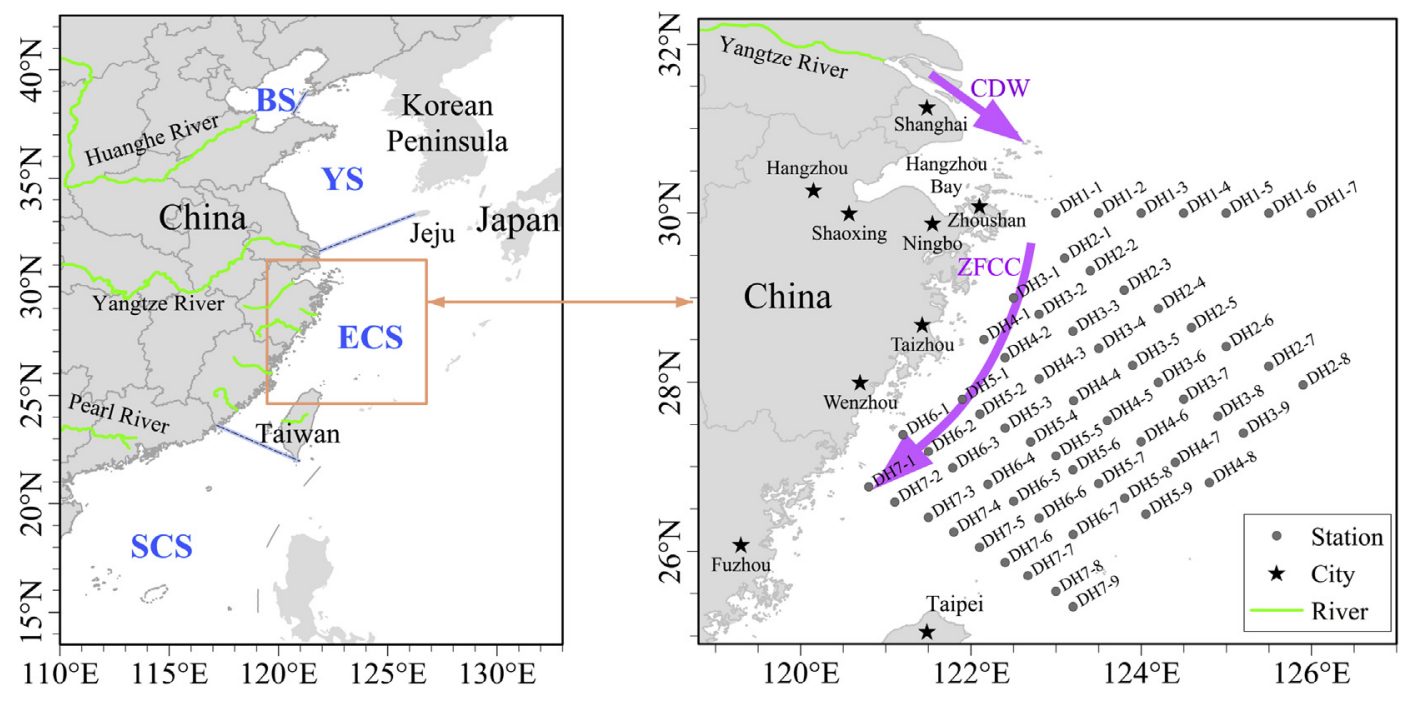

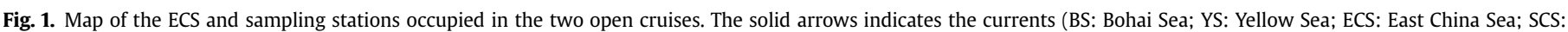
South China Sea; CDW: Changjiang Diluted Water; ZFCC: Zhejiang-Fujian Coastal Current).

10 min with a sampling flow rate of $1.51 \mathrm{~min}^{-1}$. The precision of the analyzer was determined to $>97 \%$, and the detection limit was $<0.1 \mathrm{ng} \mathrm{m}^{-3}$. Data quality was checked via periodic internal recalibrations every $25 \mathrm{~h}$. Manual injections were used to evaluate these automated calibrations before and after the cruises. The relative percent difference between manual injections and automated calibrations was less than $5 \%$. We installed the Tekran instrument inside the ship laboratory on the fourth deck of the R/V Kexue III (IOCAS) and mounted the sampling inlet at the front deck $2 \mathrm{~m}$ above the top deck (avoiding contamination) at a height of $16 \mathrm{~m}$ above sea level using a Teflon sampling tube. Particulate $\mathrm{Hg}_{\left(\mathrm{Hg}^{\mathrm{P}}\right)}$ was removed by the soda-lime trap (two pieces of pre-clean fluffy quartz wool were placed in the both ends of the soda lime trap) and the Teflon filter. Since the GEM was reported at a level at least 2 orders of magnitude higher than reactive gaseous $\mathrm{Hg}$ (RGM) in the marine boundary layer (MBL) (Chand et al., 2008; Soerensen et al., 2010a; Wang et al., 2016a,b), the atmospheric Hg measured in this study was therefore referred to as GEM.

\subsubsection{Measurements of DGM and THg in surface seawater}

In this study, all containers (including glass bottles and bubblers, etc.) were cleaned prior to use with trace-metal-grade $\mathrm{HNO}_{3}(30 \%$, $\mathrm{v} / \mathrm{v})$ and $\mathrm{HCl}(10 \%, \mathrm{v} / \mathrm{v})$ and then rinsed with Milli-Q water $\left(>18.2 \mathrm{M} \Omega \mathrm{cm}^{-1}\right)$. Moreover, powder-free gloves were worn and ultra-trace $\mathrm{Hg}$ clean techniques were applied during the whole study period (USEPA, 2002).

DGM concentrations were measured in situ using a manual method. The method of the water sampling, DGM collection and quantification described by Fu et al. (2010) and Ci et al. (2011a, d) were followed. The detailed sampling and analysis of DGM was described below: seawater was manually collected at a depth of $10-50 \mathrm{~cm}$ below the sea surface into a $1.5 \mathrm{l}$ volume Teflon bottle, which was rinsed with seawater three times prior to collection, and there was no headspace within the bottle to avoid loss of DGM by evasion to the headspace (Ci et al., 2011a). Immediately after sampling, the seawater was slowly transferred into a 1.21 borosilicate glass bubbler. A glass frit was installed at the bottom of the bubbler, and the DGM was extracted from seawater by purging the sample with $\mathrm{Hg}$-free $\mathrm{N}_{2}$ at a flow rate of $0.51 \mathrm{~min}^{-1}$ for $30 \mathrm{~min}$. A soda-lime trap was used to remove the water vapor. The extracted DGM was collected on a gold trap heated to $\sim 50{ }^{\circ} \mathrm{C}$ to avoid condensation of water vapor. The gold trap was quantified using the dual amalgamation and CVAFS method (Gill and Fitzgerald, 1987). Quality assurance and quality control for DGM were conducted using duplicates and field blanks. The analytical blank was determined onboard the R/V by extracting Milli-Q water for DGM as described above. The mean concentration of DGM blank was $2.1 \pm 1.1 \mathrm{pg} \mathrm{l}^{-1}(\mathrm{n}=12)$, accounting for $2-8 \%$ of the raw DGM in seawater samples. The method detection limit was $3.3 \mathrm{pg} \mathrm{l}^{-1}$ on the basis of three times the standard deviation of system blanks. The mean relative difference of duplicated DGM samples was $8 \pm 3 \%$ (6 pairs). The repeatability of six replicated measurements of the same sample was better than $7 \%$.

To determine $\mathrm{THg}$ concentrations, surface seawater samples were transferred carefully to precleaned borosilicate glass bottles (volume: $250 \mathrm{ml}$ ) and preserved by adding trace-metal-grade $\mathrm{HCl}$ (to $0.5 \%$ of total sample volume). The glass bottles with samples were individually sealed into three successive polyethylene bags and stored in a refrigerator $\left(4^{\circ} \mathrm{C}\right)$ during the two cruises. After the cruises, samples were transported to the laboratory and analyzed using USEPA Method 1631 (USEPA, 2002) within two weeks. The specific processes were as follows: seawater sample was oxidized with $\mathrm{BrCl}$, followed by $\mathrm{NH}_{2} \mathrm{OH} \cdot \mathrm{HCl}$ for pre-reduction, and then was reduced with $\mathrm{SnCl}_{2}$ and immediately purged using $\mathrm{Hg}$-free $\mathrm{N}_{2}$. The $\mathrm{Hg}^{0}$ was pre-concentrated on gold trap and then quantified using dual amalgamation and CVAFS detection technique (Gill and Fitzgerald, 1987). Every batch of samples was accompanied by six identically processed system blanks, and the detection limit was $0.12 \mathrm{ng} \mathrm{l}^{-1}$ based on three times the standard deviation of the system blanks $(\mathrm{n}=12)$. All reported data were corrected for the system blank in this study. The repeatability and reproducibility were $8 \%$ and $11 \%$, and recovery on matrix spike of $\mathrm{THg}$ in samples was in the range of $92-115 \%(n=6)$.

\subsubsection{Ancillary data and back-trajectory model}

The meteorological and basic seawater parameters (e.g., wind speed, seawater temperature, and salinity) were collected onboard the $\mathrm{R} / \mathrm{V}$, which is equipped with meteorological and oceanographic instrumentations. To identify the long range transport of GEM and investigate the influence of air masses movements on the GEM levels, we calculated $72 \mathrm{~h}$ back-trajectories of air masses using the HYSPLIT model (Draxler and Rolph, 2003) and TrajStat software (Wang et al., 2009) based Geographic Information System. Global Data Assimilation System (GDAS) meteorological dataset (ftp:// 
arlftp.arlhq.noaa.gov/pub/archives/gdas1/) was used as the HYSPLIT model input. The start height of back trajectory was $500 \mathrm{~m}$ above sea level, generally representing the typical height of the MBL. The start locations of back trajectories were the sampling stations, and the start time of each back trajectory was matched to the GEM sampling time (GMT).

\subsection{Air-sea $\mathrm{Hg}^{0}$ flux estimation}

The air-sea flux of $\mathrm{Hg}^{0}$ was estimated using a thin film gas exchange model developed by Liss and Slater (1974) and Wanninkhof (1992). The calculation of $\mathrm{Hg}^{0}$ flux and the discussion of its uncertainties were given in $\mathrm{Ci}$ et al. (2011a, d) in detail. It should be noted that the Schmidt number for gaseous $\mathrm{Hg}\left(S c_{\mathrm{Hg}}\right)$ is defined as equation: $S c_{\mathrm{Hg}}=\nu / D_{\mathrm{Hg}}$, where $\nu$ is the kinematic viscosity $\left(\mathrm{cm}^{2} \mathrm{~s}^{-1}\right)$ of seawater calculated using the method of Wanninkhof (1992), $D_{\mathrm{Hg}}$ is the $\mathrm{Hg}^{0}$ diffusion coefficient $\left(\mathrm{cm}^{2} \mathrm{~s}^{-1}\right)$ in seawater, which is calculated according to the recent research (Kuss, 2014). The degree of $\mathrm{Hg}^{0}$ saturation $\left(S_{\mathrm{a}}\right)$ was calculated using equation: $S_{\mathrm{a}}=H^{\prime}$ $D G M_{\text {conc. }} / G E M_{\text {conc. }}$. When the value of $S_{\mathrm{a}}$ is equal to 1 , it indicates that an equilibrium reached, otherwise it means disequilibrium.

\section{Results and discussion}

\subsection{GEM in the East China Sea}

The mean GEM concentration in fall $\left(2.20 \pm 0.58 \mathrm{ng} \mathrm{m}^{-3}\right.$, $\mathrm{n}=1181)$ was significantly higher than that in summer $\left(1.61 \pm 0.32 \mathrm{ng} \mathrm{m}^{-3}, \mathrm{n}=1505\right)(t$-test, $\mathrm{p}<0.001)$. The mean GEM concentration in summer was comparable to the background level in the Atlantic Ocean (Lamborg et al., 1999) and the Northern Hemisphere (1.5-1.7 $\mathrm{ng} \mathrm{m}^{-3}$ ) (Sprovieri et al., 2010), while high GEM concentrations in fall suggested that the ECS received $\mathrm{Hg}$ polluted air from other areas. Moreover, the GEM level in fall was higher than those in unpolluted remote oceans, such as the West Atlantic Ocean and the equatorial Pacific Ocean (Table 1), and was comparable to those at some polluted coastal sites, such as Chengshantou (2.2 $\pm 0.8 \mathrm{ng} \mathrm{m}^{-3}$, Ci et al., 2011b) in China and the Hedo Station (2.04 $\pm 0.38 \mathrm{ng} \mathrm{m}^{-3}$, Chand et al., 2008) in Japan, but lower than those in the northern South China Sea (Fu et al., 2010; Tseng et al., 2012, 2013) (Table 1). Since the ECS is located in the downwind of East Asia, the elevated GEM concentrations in East China (Huang et al., 2012; Xiu et al., 2009; Xu et al., 2013, 2015; Zhu et al., 2014) and South Korea (Nguyen et al., 2007, 2010) may have an important influence on the distribution of GEM in the ECS.

The spatial distribution of GEM in the ECS has been reported in our previous study (Wang et al., 2016a). In order to identify GEM source regions surrounding the ECS, we grouped the air masses into the following three clusters in summer and four clusters in fall (Fig. 2). The GEM showed a homogenous distribution in summer (Fig. 2a), and the mean GEM concentration in the nearshore area was comparable to that in the open sea ( $t$-test, $\mathrm{p}>0.05$ ). The prevailing wind direction was south in summer, indicating that these air masses largely originated from ocean (Fig. 2a). Cluster 1 consists of air masses originating from the South China Sea, cluster 2 consists of air masses originating from oceans and passing over the Taiwan Island and Fujian Province (China) and therefore with higher GEM concentrations compared to cluster 1 ( $t$-test, $\mathrm{p}<0.01$ ), and cluster 3 was related to lowest GEM concentrations (Table 2) during the entire study period because these air masses originated from the open area of the West Pacific Ocean. Therefore, the air masses dominantly originated from sea and ocean during summer, which could be the main reason for the low GEM concentrations in summer.

The prevailing wind direction was northwest in fall, indicating
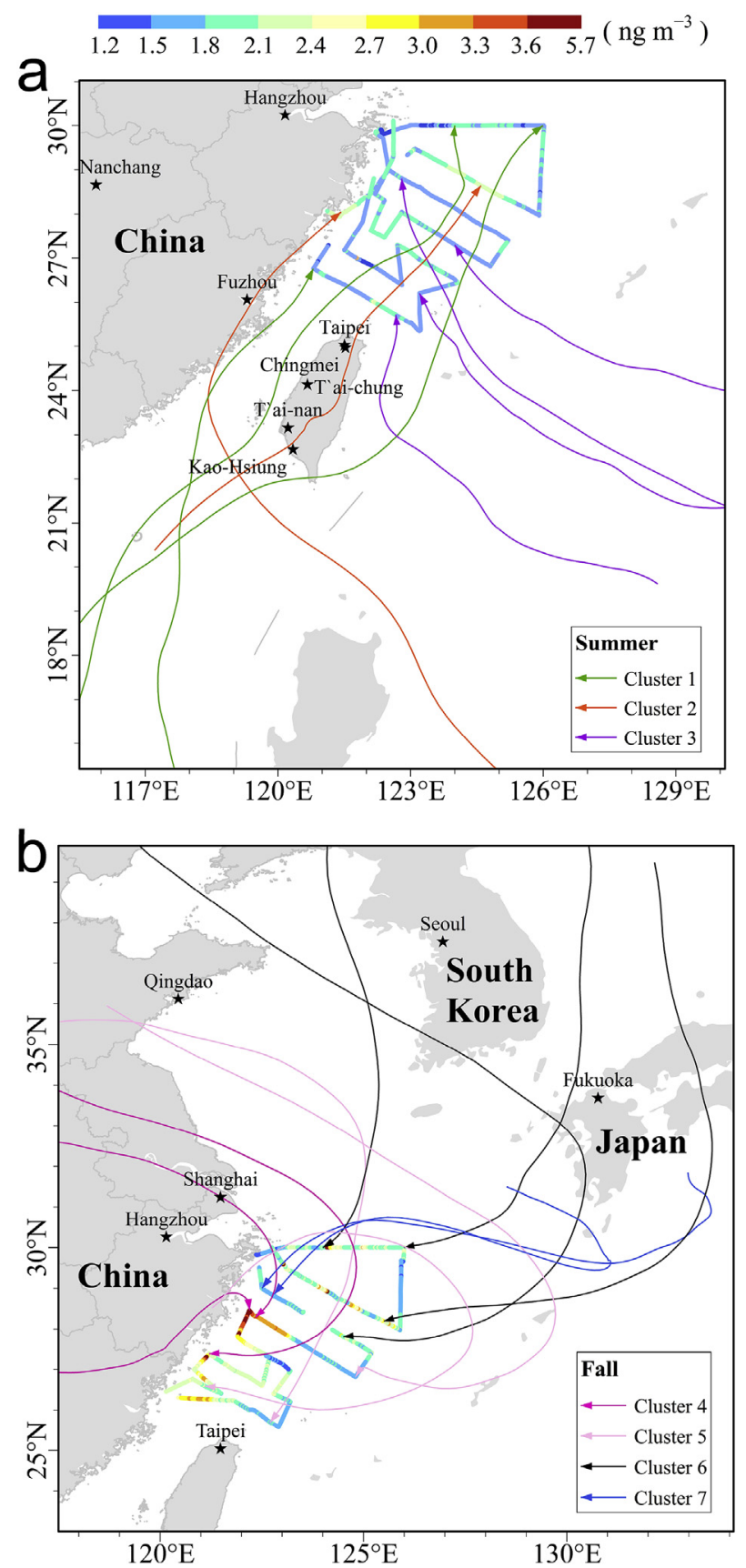

Fig. 2. GEM concentrations in the East China Sea and $72 \mathrm{~h}$ back-trajectories arriving at some stations during the summer (a) and fall (b) cruises.

that air masses largely originated from land (Fig. 2b). GEM concentrations in the nearshore area were higher than those in the open sea (Fig. 2b) probably due to the export of anthropogenic $\mathrm{Hg}$ and the dilution of $\mathrm{Hg}$ as the air masses traveling across the ECS. This pattern was consistent with the recent studies in other marine environments, such as the Yellow Sea (Ci et al., 2011d, 2015) and the northern South China Sea (Fu et al., 2010). For the four types of air masses in fall, air masses in cluster 4 originated from East China and exhibited the highest GEM concentrations (see Table 2 and Fig. 2b). Air masses in cluster 5 also originated from East China and transported a long distance over the ECS, and air masses in cluster 6 originated from the northeast China and Japan Sea and then passed over the Korea Peninsula and Japan, thus air masses in cluster 5 and cluster 6 exhibited the lower GEM concentrations compared to 
Table 2

GEM concentrations $\left(\mathrm{ng} \mathrm{m}^{-3}\right.$ ) in the air masses of seven different clusters.

\begin{tabular}{|c|c|c|c|c|c|c|c|}
\hline & \multicolumn{3}{|l|}{ Summer } & \multicolumn{4}{|l|}{ Fall } \\
\hline & Cluster 1 & Cluster 2 & Cluster 3 & Cluster 4 & Cluster 5 & Cluster 6 & Cluster 7 \\
\hline Mean & 1.51 & 2.21 & 1.45 & 3.14 & 1.87 & 2.24 & 1.78 \\
\hline SD & 0.18 & 0.10 & 0.11 & 0.42 & 0.16 & 0.31 & 0.06 \\
\hline Median & 1.51 & 2.21 & 1.47 & 3.20 & 1.83 & 2.18 & 1.77 \\
\hline Min. & 1.21 & 2.04 & 1.22 & 2.35 & 1.59 & 1.64 & 1.68 \\
\hline Max. & 1.81 & 2.54 & 1.71 & 3.99 & 2.19 & 2.94 & 1.92 \\
\hline $\mathrm{N}$ & 51 & 57 & 54 & 59 & 36 & 55 & 39 \\
\hline
\end{tabular}

those in cluster 4 (Table 2). Air masses in cluster 7 originated from the West Pacific Ocean off southern Japan, and this is probably the reason for the lowest GEM level in cluster 7 compared to the other clusters during fall (Table 2). Our results show that the anthropogenic emissions of $\mathrm{Hg}$ from the East Asia (mainly China) have affected the $\mathrm{Hg}$ distribution in the ECS during fall. As a consequence, GEM concentrations showed a pronounced dependence on the air masses movement patterns during the two cruises. However, there was no data on the atmospheric $\mathrm{Hg}$ and ancillary parameters in spring and winter, and thus we should do more research work in the future.

\section{2. $\mathrm{THg}$ and DGM in the East China Sea}

\subsection{1. $\mathrm{THg}$ in surface seawater during fall}

The mean THg concentration in surface seawater during fall was $1.45 \pm 0.62 \mathrm{ng} \mathrm{l}^{-1}(\mathrm{n}=38)$ with a range of $0.87-3.66 \mathrm{ng} \mathrm{l}^{-1}$ (Fig. 3 and Table S2), which was higher than those in other oceans and sea, such as the North and Central Pacific Ocean $\left(0.23 \pm 0.17 \mathrm{ng} \mathrm{l}^{-1}\right.$, Laurier et al., 2004), the Atlantic Ocean (0.12-0.94 $\mathrm{ng} \mathrm{l}^{-1}$, Soerensen et al., 2013), and the Mediterranean Sea $\left(0.26 \pm 0.10 \mathrm{ng} \mathrm{l}^{-1}\right.$, Kotnik et al., 2007), and was comparable to those in the northern South China Sea (1.2 $\pm 0.3 \mathrm{ng} \mathrm{l}^{-1}$, Fu et al., 2010) and at the more open sea sites of the Minamata Bay $\left(1.13 \pm 0.59 \mathrm{ng} \mathrm{l}^{-1}\right.$, Marumoto and Imai, 2015), but lower than those in several coastal sites, such as the Chengshantou (2.68 $\pm 0.78 \mathrm{ng} \mathrm{l}^{-1}$, Ci et al., 2011c) and the Minamata Bay $\left(2.68 \pm 1.97 \mathrm{ng} \mathrm{l}^{-1}\right.$, Marumoto and Imai, 2015).

The spatial distribution of THg during fall is illustrated in Fig. 3. Elevated $\mathrm{THg}$ concentrations were observed in the nearshore area of the Ningbo and Zhoushan Islands, Zhejiang Province (belonging to the Yangtze River Delta Economic Rim), one of the most industrialized and contaminated coastal environments, while low $\mathrm{THg}$ concentrations were measured in the open sea (Fig. 3). This is due

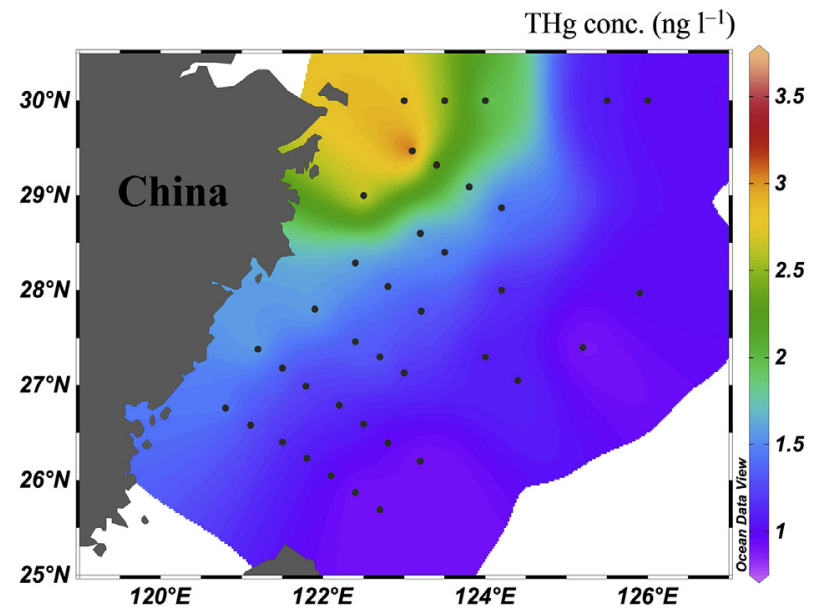

Fig. 3. Surface seawater THg concentrations at sampling stations during fall. Sampling stations are shown as black dots. to the fact that some coastal watersheds along the northwestern ECS have been polluted by rivers discharge, which brings high concentrations of trace metals. Previous studies have shown that the lower reach Yangtze River (THg: 0.25-0.73 $\mu \mathrm{g} \mathrm{l}^{-1}$, Zhang et al., 2011) and Qiantang River waters had been severely contaminated by Hg pollutant (THg: $0.10 \pm 0.02 \mu \mathrm{g} \mathrm{l}^{-1}$, Su et al., 2013). Results further show that samples taken close to the coast $\left(1.78 \pm 0.63 \mathrm{ng} \mathrm{l}^{-1}, \mathrm{n}=21\right)$ were on average $70 \%$ higher than in the open ECS $\left(1.04 \pm 0.12 \mathrm{ng} \mathrm{l}^{-1}, \mathrm{n}=17\right)$ and 7 times higher than in the Pacific surface ocean (Laurier et al., 2004), indicating that the Mainland China constituted a significant Hg source to the ECS. This $\mathrm{THg}$ distribution pattern was consistent with the previous modeled THg concentrations at the surface ocean (Zhang et al., 2015b). We speculate that there are at least three reasons for the higher $\mathrm{THg}$ concentrations in the nearshore area: a) the $\mathrm{Hg}^{\mathrm{P}} 10$ (the total $\mathrm{Hg}$ in $\mathrm{PM}_{10}$ ) concentrations in the nearshore areas were higher than those in the open sea (Wang et al., 2016a), and the higher $\mathrm{Hg}^{\mathrm{P}} 10$ concentrations may result in high deposition of $\mathrm{Hg}$ and then induce high THg levels in seawater; b) the rivers (including the Yangtze, Qiantang, Oujiang, and Minjiang Rivers etc.) discharge; c) the elevated suspended particulate matter in the nearshore area due to the resuspension of bottom sediment.

\subsubsection{Spatial distribution of DGM in the East China Sea}

Fig. 4 shows the spatial distributions of DGM in surface seawater during the summer and fall cruises. DGM varied from 29.9-100.2 $\mathrm{pg}^{-1}$ in summer (Fig. 4a and Table S1) and 27.1-75.7 $\mathrm{pg} \mathrm{l}^{-1}$ in fall (Fig. 4b and Table S2), respectively. The mean DGM concentration in summer $\left(60.1 \pm 17.6 \mathrm{pg} \mathrm{l}^{-1}\right)$ was significantly higher than that in fall $\left(49.6 \pm 12.5 \mathrm{pg} \mathrm{l}^{-1}\right)(t$-test, $\mathrm{p}<0.05)$, and this seasonal pattern has been reported in the Yellow Sea ( $\mathrm{Ci}$ et al., 2011a,d; 2015) and the northern South China Sea (Tseng et al., 2013). Previous studies have suggested that many factors, such as high solar radiation, surface water temperature, and elevated microbial activities, will promote the DGM formation in warm season (Ci et al., 2011a; Rolfhus and Fitzgerald, 2004; Tseng et al., 2013). As listed in Table 1, the DGM concentrations in the ECS both in summer and fall were higher than those of other marginal seas (e.g., the Baltic Sea and the Mediterranean Sea) and open oceans (e.g., the West Atlantic Ocean, the South Pacific Ocean, and the Atlantic Ocean), but lower than that in the Minamata Bay. The DGM concentration in summer was comparable to those at Chengshantou and the open sea area of the Yellow Sea (Table 1). The DGM concentration in fall was comparable to that in the Tokyo Bay, but higher than those in the Yellow Sea (fall) and the northern South China Sea (Table 1). The higher THg and DGM levels in the ECS (Table 1) as compared to those of other open oceans suggested that the ECS was contaminated by $\mathrm{Hg}$.

The DGM in surface seawater of the ECS was supersaturated with a saturation of $599-2500 \%$ with a mean value of $1340 \pm 466 \%$ in summer and $404-1156 \%$ with a mean value of $707 \pm 170 \%$ in fall, indicating that $\mathrm{Hg}^{0}$ evaded from the surface seawater to the atmosphere during the entire study period. Fig. 4 shows that the 

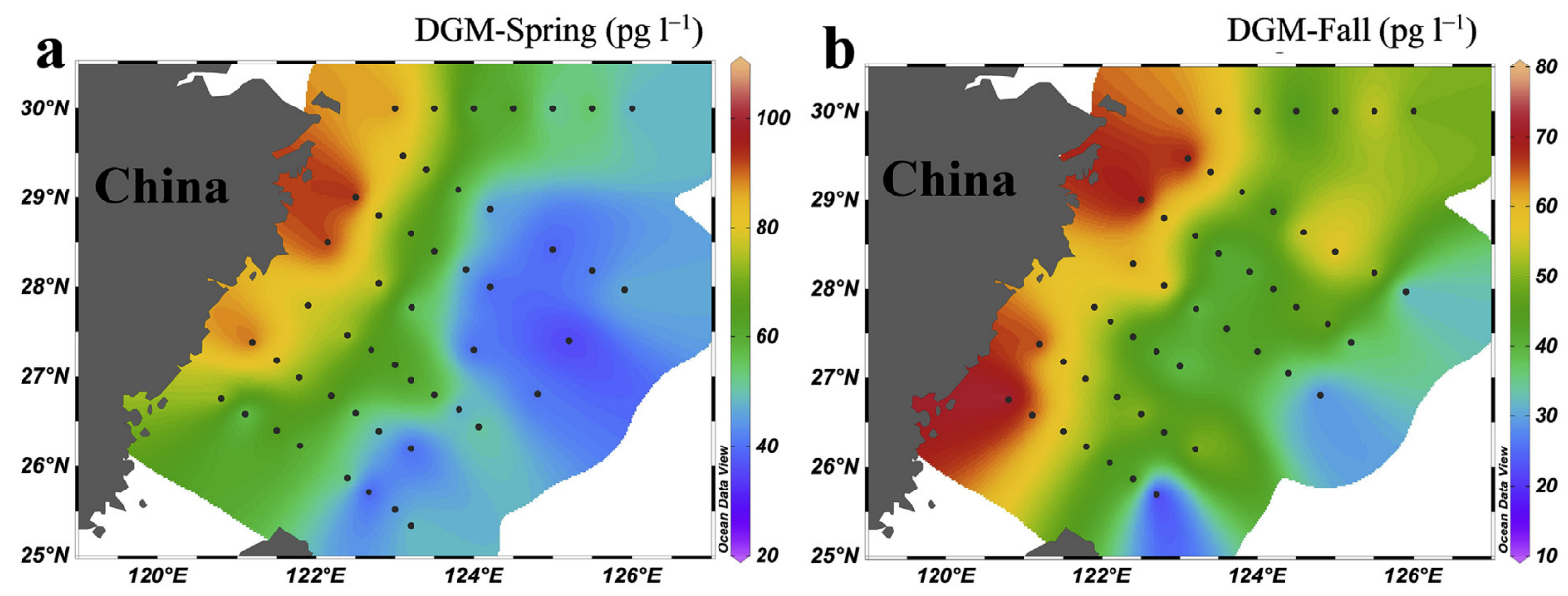

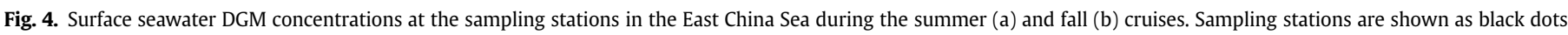

DGM concentrations in the nearshore area were higher than those in the open sea both in summer and fall. During summer, the mean DGM concentration of the 7 stations closest to the land was significantly higher than that of 7 stations furthest away ( $t$-test, $\mathrm{p}<0.01$ ) (see Fig. 4a and Table S1), and a similar result ( $t$-test, $\mathrm{p}<0.01$ ) was obtained during fall, suggesting more DGM was produced in the nearshore area. This is due to the fact that the $\mathrm{THg}$ concentrations in nearshore area were higher than those in the open sea (Fig. 3). Recent study (Ci et al., 2016) has shown that the reducible $\mathrm{Hg}(\mathrm{II})$ was positively correlated with $\mathrm{THg}$, and there was more $\mathrm{Hg}^{0}$ production in seawater with higher levels of $\mathrm{THg}$. The significant differences in THg and DGM concentrations between the coastal sites and the more open sea sites indicated that these $\mathrm{Hg}$ species may be sourced from land and/or that THg discharged into the coastal area induces the production of DGM.

In this study, the mean DGM concentration in the daytime (summer: $62.1 \pm 22.1 \mathrm{pg} \mathrm{l}^{-1}$; fall: $51.7 \pm 11.6 \mathrm{pg} \mathrm{l}^{-1}$ ) was comparable to that in the nighttime (summer: $60.4 \pm 17.6 \mathrm{pg} \mathrm{l}^{-1}$; fall: $52.2 \pm 21.3 \mathrm{pg} \mathrm{l}^{-1}$ ) in corresponding season ( $t$-test, $\mathrm{p}>0.05$ for both summer and fall). This pattern was in agreement with the results observed in the West Atlantic Ocean (Soerensen et al., 2013) and the Yellow Sea (Ci et al., 2015). This is probably due to the following reasons: a) the high wind speed promotes the mixture of upper ocean water, resulting in the surface seawater not building up high $\mathrm{Hg}^{0}$ concentration during daytime; b) microbial transformation seemed to play an important role in reducing $\mathrm{Hg}$ (II) to $\mathrm{Hg}^{0}$ (Ahn et al., 2010) since it occurs during the whole day. As shown in Fig. 5, the \%DGM levels in the open sea were higher than those in the coastal area, but there was no significant difference in \%DGM between the coastal sites and the more open sea sites ( $t$-test, $\mathrm{p}>0.05$ ) (Table S2). This is probably due to the fact that the DGM and $\mathrm{THg}$ concentrations in the nearshore area were all higher than those in the open sea. This distribution pattern of \%DGM was consistent with the results of previous studies (Baeyens and Leermakers, 1998; Schartup et al., 2015; Soerensen et al., 2013). In addition, we found that \%DGM at the coastal stations of the Zhoushan Island was lower than those other stations. This can be explained by the high THg (Fig. 3) and DOC (Gan et al., 2015) concentrations at the coastal stations of the Zhoushan Island since the high DOC concentrations may result in the enhanced stability of $\mathrm{Hg}$ (II) complexes with DOC (Soerensen et al., 2013).

\subsubsection{Relationships between DGM, \%DGM, and ancillary} parameters

Fig. S1 and Fig. S2 show the spatial distributions of salinity,

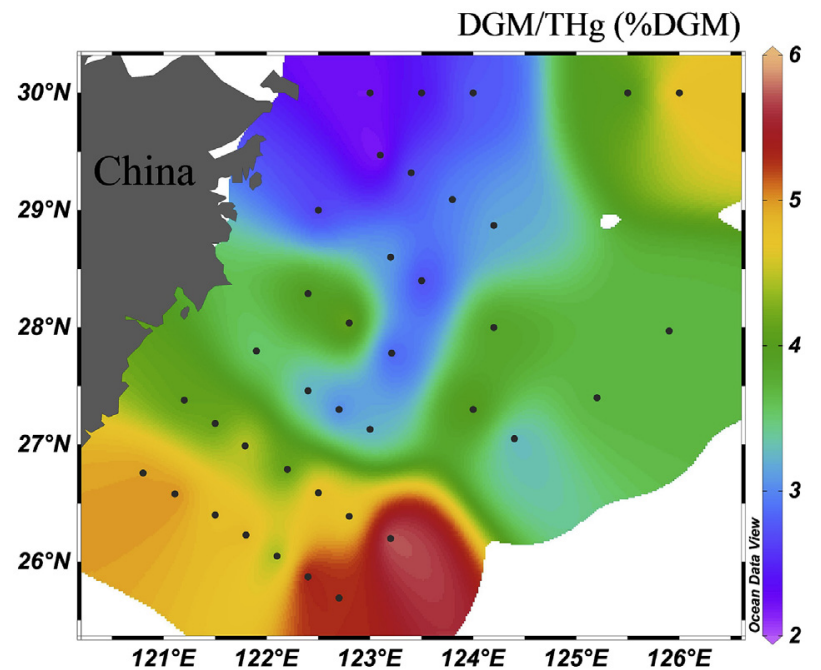

Fig. 5. The distribution of surface seawater percentage of DGM to THg (\%DGM) in the East China Sea during the fall cruise of 2013. Sampling stations are shown as black dots.

turbidity (Formazin Turbidity Unit, FTU), dissolved oxygen (DO), and in situ fluorescence (a proxy for algal productivity) in the surface seawater of the ECS during summer and fall, respectively. The specific values of ancillary parameters are given in Table S3. The results show that the salinity levels at coast near the Hangzhou Bay and Yangtze River Delta were lower than those of other open sea both in summer and fall (Fig. S1a and Fig. S2e). This is mainly because the Yangtze River and Qiantang River provide a substantial input of freshwater (e.g., the CDW) into adjacent sea (see Fig. 1), and then the freshwater diluted the salinity of the coastal waters. There was no distinct distribution pattern of DO both in summer and fall (Fig. S1c and Fig. S2g) probably because the horizontal transport of DO in surface seawater is mainly balanced by reaeration (Zhang and Li, 2010). There was no significant correlation between DGM, \% DGM, and DO during the whole study period (Table 3). Additionally, we found that the fluorescence values tended to decrease from the coastal areas to the open sea both in summer and fall (Fig. S1d and Fig. S2h), and one reason was that the algal concentrations in the nearshore area were higher than those in the open sea.

Table 3 shows the correlation coefficients obtained for the relationships between DGM, \%DGM, and surface seawater parameters as well as meteorological parameters. Correlation analysis shows that a significantly positive correlation was found between DGM and 
fluorescence (Table 3). Previous studies have shown that microorganism activities are considered as another principal force for the $\mathrm{Hg}$ (II) reduction to DGM except photoreduction (Fantozzi et al., 2009; Lanzillotta et al., 2004), since it occurs continuously along the entire water column throughout the whole day. Recently, Wu and Wang (2014) found that all algae tested were able to transform $\mathrm{Hg}$ (II) into DGM. In addition, the photoreduction rate of $\mathrm{Hg}$ (II) increased with increasing algae concentration (Deng et al., 2008). However, further research is needed to elucidate the influence of algae on the DGM formation. Because elevated organic materials (e.g., algae and plankton) and inorganic materials (e.g., silt and sediment) can increase the turbidity (Kemker, 2014), there was a significantly positive correlation between DGM and surface water turbidity in this study because of the activities of organic materials. As such, turbidity and total suspended solids were related. Previous study has shown that the surface suspended particulate matter concentrations in the coastal sea area (within $100 \mathrm{~km}$ from land) of the ECS were significantly higher than those in the open sea (Wang et al., 2011), which was consistent with the turbidity distribution pattern in this study. Our results show that the turbidity values in the nearshore area were also higher than those in the open sea (Fig. S1b and Fig. S2f) due to the shallow coastal waters (high wind speed can enhance resuspension of sediments), the rivers discharge, and the special ZFCC current pattern (see Fig. 1).

During summer, we found that DGM was positively correlated with PAR (Table 3 ) though the production of DGM requires a certain time span since the DGM production in surface seawater is mainly driven by photochemical processes (Kuss et al., 2015). The fundamental role of sunlight in the formation of DGM had been proved by the existence of a daily and seasonal behaviour of the DGM concentration in seawater (Ci et al., 2011a, 2016; Lanzillotta and Ferrara, 2001; Lanzillotta et al., 2002; Tseng et al., 2013). In contrast, the \% DGM was significantly negatively correlated with the $\mathrm{THg}$ and fluorescence due to the high $\mathrm{THg}$ and fluorescence levels in nearshore area. Additionally, we found that \%DGM was positively correlated with salinity during fall (Table 3), which was consistent with the previous studies (Schartup et al., 2015; Soerensen et al., 2013).

\subsection{Air-sea exchange of $\mathrm{Hg}^{0}$ in the East China Sea}

The air-sea exchange fluxes of $\mathrm{Hg}^{0}$ during summer and fall are presented in Table S1 and Table S2 respectively, including atmospheric GEM, surface seawater DGM and THg, water temperature, wind speed of $10 \mathrm{~m}$ above sea level, and saturation of $\mathrm{Hg}^{0}$. Air-sea fluxes of $\mathrm{Hg}^{0}$ in the ECS varied from 0.2 to $14.8 \mathrm{ng} \mathrm{m}^{-2} \mathrm{~h}^{-1}$ in summer and $0.3-11.5 \mathrm{ng} \mathrm{m}^{-2} \mathrm{~h}^{-1}$ in fall. There was no significant difference in $\mathrm{Hg}^{0}$ flux between summer $\left(4.6 \pm 3.4 \mathrm{ng} \mathrm{m}^{-2} \mathrm{~h}^{-1}\right)$ and fall $\left(3.6 \pm 2.8 \mathrm{ng} \mathrm{m}^{-2} \mathrm{~h}^{-1}\right)(t$-test, $\mathrm{p}>0.05)$. The mean $\mathrm{Hg}^{0}$ flux during the entire study period was $4.1 \pm 3.2 \mathrm{ng} \mathrm{m}^{-2} \mathrm{~h}^{-1}$, which was comparable to the measurements in the Mediterranean Sea, the northern South China Sea, and the West Atlantic Ocean, and lower than those of polluted marine environments, such as the Tokyo Bay, the Minamata Bay, and the Yellow Sea, but higher than those of some other marginal seas (e.g., the Baltic Sea) and open oceans (e.g., the Atlantic Ocean and the South Pacific Ocean) (Table 1).
The results reported at coast site (Chengshantou) of the Yellow Sea suggested that the $\mathrm{Hg}^{0}$ flux in summer was comparable to that in fall (Ci et al., 2011a), but both of them were much lower than our data due to the lower wind speed (summer) and DGM concentration (fall) in the Yellow Sea (Table 1). The $\mathrm{Hg}^{0}$ fluxes observed in the Mediterranean Sea exhibited similar values between summer and fall (Andersson et al., 2007), which were comparable to our result due to the higher wind speed in their study period though the average DGM concentrations in the Mediterranean Sea were lower than those of our study area (see Table 1). Recent studies in the Yellow Sea showed that the mean $\mathrm{Hg}^{0}$ flux (summer) in the Yellow Sea (Ci et al., 2011d) was considerably higher than that at the Chengshantou ( $\mathrm{Ci}$ et al., 2011a) due to the significantly higher wind speed in the Yellow Sea though the DGM levels in the Yellow Sea and Chengshantou were comparable. Additionally, the results observed at the SEATS station in the northern South China Sea (Tseng et al., 2013) showed that the mean $\mathrm{Hg}^{0}$ flux in fall was higher than that in summer due to the higher wind speed in fall compared to in summer though the DGM concentrations were higher in summer than in fall (see Table 1 ).

During the summer cruise, $\mathrm{Hg}^{0}$ flux at station DH4-4 were much higher than that at station DH5-1, but DGM concentrations were opposite for the two stations (see Table S1). The strong relationship between wind speed $\left(u_{10}\right)$ and $\mathrm{Hg}^{0}$ flux $(\mathrm{r}=0.823, \mathrm{p}<0.001)$ suggested that wind speed plays an important role in the $\mathrm{Hg}^{0}$ exchange between the air-sea interface, and the similar result can also be found during the fall cruise (see Table S2). This finding was consistent with the results obtained by Ci et al. (2011d, 2015), Fantozzi, et al. (2013), and Tseng et al. (2013). The main reason is that the two-layer exchange model used to calculate air-sea $\mathrm{Hg}^{0}$ flux is very sensitive to the wind speed (Andersson et al., 2007; Ci et al., 2011a; Sharif et al., 2013). Through the discussions mentioned above, it finally draws the conclusion that the wind speed plays an important role in the air-sea flux of $\mathrm{Hg}^{0}$. Additionally, $\mathrm{Hg}^{0}$ levels at the air-sea interface and water temperature are another two important driving factors for the $\mathrm{Hg}^{0}$ flux (Andersson et al., 2011; Tseng et al., 2013). Furthermore, many factors may affect the $\mathrm{Hg}^{0}$ flux except the wind speed, Andersson et al. (2007) compared five algorithms that widely used for calculating the gas transfer coefficient and suggested that there was great difference between these algorithms at high wind speed (e.g., $>10 \mathrm{~m} \mathrm{~s}^{-1}$ ), the choice of $D_{\mathrm{Hg}}$ also influences the calculation of air-sea $\mathrm{Hg}^{0}$ flux.

In order to relate this data to the global estimation, an approximate monthly air-sea flux of $\mathrm{Hg}^{0}$ from the ECS was calculated using the average monthly wind speed and water temperature. A monthly average net $\mathrm{Hg}^{0}$ evasion of $3.28 \mu \mathrm{g} \mathrm{m}^{-2}$ month ${ }^{-1}$ and $2.62 \mu \mathrm{g} \mathrm{m}^{-2}$ month $^{-1}$ was calculated in summer and fall. If we take the average monthly net evasion of $\mathrm{Hg}^{0}$ in summer and fall as an approximate annual $\mathrm{Hg}^{0}$ evasion rate, the annual emission flux of $\mathrm{Hg}^{0}$ from the ECS was 27.3 tons $\mathrm{yr}^{-1}$ assuming the area of the ECS was $7.7 \times 10^{11} \mathrm{~m}^{2}$ (accounting for $\sim 0.21 \%$ of the global ocean area), which represented about $0.95 \%$ of the global $\mathrm{Hg}^{0}$ oceanic evasion (2880 tons $\mathrm{yr}^{-1}$, Soerensen et al., 2010b; Strode et al., 2007). Therefore, the ECS may actually play an important role in the global $\mathrm{Hg}$ oceanic evasion. One probable reason was that the DGM

Table 3

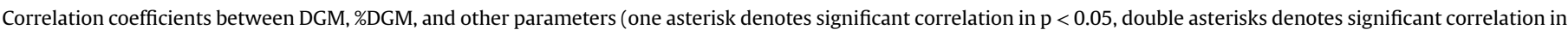
$\mathrm{p}<0.01)$.

\begin{tabular}{|c|c|c|c|c|c|c|}
\hline & $\mathrm{THg}$ & PAR & Salinity & DO & Fluorescence & Turbidity \\
\hline DGM (summer) & $\mathrm{NA}^{\mathrm{a}}$ & $0.360^{*}$ & $-0.357^{*}$ & 0.157 & $0.651^{* *}$ & $0.530^{* *}$ \\
\hline DGM (fall) & $0.428^{* *}$ & $N A^{a}$ & $-0.484^{* *}$ & 0.042 & $0.511^{* *}$ & $0.694^{* *}$ \\
\hline$\% \mathrm{DGM}^{\mathrm{b}}$ (fall) & $-0.628^{* *}$ & $\mathrm{NA}^{\mathrm{a}}$ & 0.115 & -0.143 & $-0.398^{*}$ & -0.108 \\
\hline
\end{tabular}

a NA denotes not available.

b \%DGM denotes the percentages of DGM to THg. 
concentrations in the ECS were higher than those of other open seas due to the riverine input and atmospheric wet and dry deposition of atmospheric Hg. It should be noted that the DGM concentrations in winter and spring probably lower than those in summer, but we have no data on the DGM concentrations in spring and winter. More research works are needed in the future. The seasonal cycling and spatial distribution of $\mathrm{Hg}^{0}$ fluxes were not considered in this study, and there were no data on fluxes of $\mathrm{Hg}^{0}$ in winter and spring, which probably led to an overestimation or underestimation of the annual $\mathrm{Hg}^{0}$ flux.

\section{Conclusions}

The GEM, DGM, THg, and air-sea flux of $\mathrm{Hg}^{0}$ were investigated in the ECS for the first time. The spatial distributions of GEM in the atmosphere and $\mathrm{THg}$ in surface seawater during fall reflected a pattern with high levels near the coast of Southeast China and low levels in the open sea, suggesting significant $\mathrm{Hg}$ outflow from China. However, this pattern was not distinct for GEM during summer due to the predominant wind direction was south and most of the air masses originated from ocean. Moreover, the DGM concentrations in the nearshore area were higher than those in the open sea. This is due to the fact that the THg and DOC levels in the coastal sea area were higher than those in the open sea. We found that the mean DGM concentration during the daytime was comparable to that during the nighttime both in summer and fall. The \% DGM in the open sea area was higher than that in the nearshore area, but there was no significant difference in \%DGM between the nearshore area and open sea. The $\mathrm{Hg}^{0}$ fluxes were all positive during the whole study period, indicating that the exchange of $\mathrm{Hg}^{0}$ was from the surface seawater to the atmosphere. Finally, the estimated emission flux of $\mathrm{Hg}^{0}$ in the ECS was higher than the average $\mathrm{Hg}^{0}$ flux of global oceans although estimation of $\mathrm{Hg}^{0}$ flux remains uncertainties.

\section{Acknowledgments}

This research was financially supported by National Key Basic Research Program of China (No. 2013CB430002), National Natural Science Foundation of China (No. 41176066; 41203068; 41371461; 41573117), and "Strategic Priority Research Program" of the Chinese Academy of Sciences (No. XDB14020205). We gratefully acknowledge the open cruises in 2013 organized by the Institute of Oceanology Chinese Academy of Sciences (IOCAS). The authors would like to thank the staff of the R/V Kexue III for their technical assistance. We thank the reviewers for their valuable comments and suggestions.

\section{Appendix A. Supplementary data}

Supplementary data related to this article can be found at http:// dx.doi.org/10.1016/j.envpol.2016.03.016.

\section{References}

Ahn, M.C., Kim, B., Holsen, T.M., Yi, S.M., Han, Y.J., 2010. Factors influencing concentrations of dissolved gaseous mercury (DGM) and total mercury (TM) in an artificial reservoir. Environ. Pollut. 158, 347-355.

Andersson, M.E., Gårdfeldt, K., Wängberg, I., Sprovieri, F., Pirrone, N., Lindqvist, O., 2007. Seasonal and daily variation of mercury evasion at coastal and off shore sites from the Mediterranean Sea. Mar. Chem. 104, 214-226.

Andersson, M.E., Sommar, J., Gårdfeldt, K., Jutterström, S., 2011. Air-sea exchange of volatile mercury in the North Atlantic Ocean. Mar. Chem. 125, 1-7.

Baeyens, W., Leermakers, M., 1998. Elemental mercury concentrations and formation rates in the Scheldt estuary and the North Sea. Mar: Chem. 60, 257-266.

Bowman, K.L., Hammerschmidt, C.R., Lamborg, C.H., Swarr, G., 2015. Mercury in the North Atlantic Ocean: the U.S. Geotraces zonal and Meridional sections. Deep Sea Res. Part II 116, 251-261.
Chand, D., Jaffe, D., Prestbo, E., Swartzendruber, P.C., Hafner, W., Weiss-Penzias, P., Kato, S., Takami, A., Hatakeyama, S., Kajii, Y., 2008. Reactive and particulate mercury in the Asian marine boundary layer. Atmos. Environ. 42, 7988-7996.

Chen, Y., Yang, G., Liu, L., Zhang, P., Leng, W., 2016. Sources, behaviors and degradation of dissolved organic matter in the East China Sea. J. Mar. Syst. 155, 84-97.

Choy, C.A., Popp, B.N., Kaneko, J.J., Drazen, J.C., 2009. The influence of depth on mercury levels in pelagic fishes and their prey. Proc. Natl. Acad. Sci. U. S. A. 106, 13865-13869.

Ci, Z., Zhang, X. Wang, Z., 2011a. Elemental mercury in coastal seawater of Yellow Sea, China: temporal variation and air-sea exchange. Atmos. Environ. 45, 183-190.

Ci, Z., Zhang, X., Wang, Z., Niu, Z., 2011b. Atmospheric gaseous elemental mercury (GEM) over a coastal/rural site downwind of East China: temporal variation and long-range transport. Atmos. Environ. 45, 2480-2487.

Ci, Z., Zhang, X., Wang, Z., Niu, Z., 2011c. Phase speciation of mercury (Hg) in coastal water of the Yellow Sea, China. Mar. Chem. 126, 250-255.

Ci, Z., Zhang, X., Wang, Z., Niu, Z., Diao, X., Wang, S., 2011d. Distribution and air-sea exchange of mercury (Hg) in the Yellow Sea. Atmos. Chem. Phys. 11, 2881-2892.

Ci, Z., Zhang, X., Wang, Z., Wang, C., 2014. Mass balance of mercury for the Yellow Sea downwind and downstream of East Asia: the preliminary results, uncertainties and future research priorities. Biogeochemistry 118, 243-255.

Ci, Z., Wang, C., Zhang, X., Wang, Z., 2015. Elemental mercury $(\operatorname{Hg}(0))$ in air and surface waters of the Yellow Sea during late spring and late fall 2012: concentration, spatial-temporal distribution and air/sea flux. Chemosphere 119 199-208.

Ci, Z., Zhang, X., Yin, Y., Chen, J., Wang, S., 2016. Mercury redox chemistry in waters of the eastern Asian seas: from polluted coast to clean open ocean. Environ. Sci. Technol. 50, 2371-2380.

Deng, L., Wu, F., Deng, N., Zuo, Y., 2008. Photoreduction of mercury(II) in the presence of algae, Anabaena cylindrical. J. Photochem. Photobio. B 91, 117-124.

Draxler, R.R., Rolph, G.D., 2003. HYSPLIT (HYbrid Single Particle Lagrangian Integrated Trajectory) Model. NOAA Air Resources Laboratory, Silver Spring, MD access via NOAA ARL READY Website. Available at: http://www.arl.noaa.gov ready/hysplit4.html.

Duan, L., Song, J., Yu, Y., Yuan, H., Li, X., Li, N., 2015. Spatial variation, fractionation and sedimentary records of mercury in the East China Sea. Mar. Pollut. Bull. 101, 434-441.

Fang, T.H., Chen, R.Y., 2010. Mercury contamination and accumulation in sediments of the East China Sea. J. Environ. Sci. 22, 1164-1170.

Fantozzi, L., Ferrara, R., Frontini, F.P., Dini, F., 2009. Dissolved gaseous mercury production in the dark: evidence for the fundamental role of bacteria in different types of Mediterranean water bodies. Sci. Total Environ. 407, 917-924.

Fantozzi, L., Manca, G., Ammoscato, I., Pirrone, N., Sprovieri, F., 2013. The cycling and sea-air exchange of mercury in the waters of the Eastern Mediterranean during the 2010 MED-OCEANOR cruise campaign. Sci. Total Environ. 448, 151-162.

Fu, X., Feng, X., Zhang, G., Xu, W., Li, X., Yao, H., Liang, P., Li, J., Sommar, J., Yin, R., Liu, N., 2010. Mercury in the marine boundary layer and seawater of the South China Sea: concentrations, sea/air flux, and implication for land outflow. J. Geophys. Res. 115. D06303. http://dx.doi.org/10.1029/2009JD012958.

Gan, S., Wu, Y., Zhang, J., 2015. Bioavailability of dissolved organic carbon linked with the regional carbon cycle in the East China Sea. Deep Sea Res. Part II. 124, $19-28$.

Gårdfeldt, K., Sommar, J., Ferrara, R., Ceccarini, C., Lanzillotta, E., Munthe, J. Wängberg, I., Lindqvist, O., Pirrone, N., Sprovieri, F., Pesenti, E., Strömberg, D. 2003. Evasion of mercury from coastal and open waters of the Atlantic Ocean and the Mediterranean Sea. Atmos. Environ. 37, S73-S84.

Gill, G.A., Fitzgerald, W.F., 1987. Picomolar mercury measurements in seawater and other materials using stannous chloride reduction and two-stage gold amalgamation with gas phase detection. Mar. Chem. 20, 227-243.

Han, F., Shan, X.Q., Zhang, S.Z., Wen, B., 2004. Mercury speciation in China's coastal surface seawater. Int. J. Environ. Anal. Chem. 84, 583-598.

Hammerschmidt, C.R., Bowman, K.L., 2012. Vertical methylmercury distribution in the subtropical North Pacific Ocean. Mar. Chem. 132-133, 77-82.

Huang, J., Liu, C.K., Huang, C.S., Fang, G.C., 2012. Atmospheric mercury pollution at an urban site in central Taiwan: mercury emission sources at ground level. Chemosphere 87, 579-585.

Kemker, C., 2014. Turbidity, Total Suspended Solids and Water Clarity. In: Fundamentals of Environmental Measurements. Fondriest Environmental. Web. Available at: http://www.fondriest.com/environmental-measurements/ parameters/water-quality/turbidity-total-suspended-solids-water-clarity/.

Kotnik, J., Horvat, M., Tessier, E., Ogrinc, N., Monperrus, M., Amouroux, D., Fajon, V., Gibičar, D., Žižek, S., Sprovieri, F., Pirrone, N., 2007. Mercury speciation in surface and deep waters of the Mediterranean Sea. Mar. Chem. 107, 13-30.

Kuss, J., Schneider, B., 2007. Variability of the gaseous elemental mercury sea-air flux of the Baltic Sea. Environ. Sci. Technol. 41, 8018-8023.

Kuss, J., Zülicke, C., Pohl, C., Schneider, B., 2011. Atlantic mercury emission determined from continuous analysis of the elemental mercury sea-air concentration difference within transects between $50^{\circ} \mathrm{N}$ and $50^{\circ} \mathrm{S}$. Glob. Biogeochem. Cycles 25, GB 3021. http://dx.doi.org/10.1029/2010GB003998.

Kuss, J., 2014. Water-air gas exchange of elemental mercury: an experimentally determined mercury diffusion coefficient for $\mathrm{Hg}^{0}$ water-air flux calculations. Limnol. Oceanogr. 59, 1461-1467.

Kuss, J., Wasmund, N., Nausch, G., Labrenz, M., 2015. Mercury emission by the Baltic Sea: a consequence of cyanobacterial activity, photochemistry, and low-light mercury transformation. Environ. Sci. Technol. 49, 11449-11457. 
Lamborg, C.H., Rolfhus, K.R., Fitzgerald, W.F., Kim, G., 1999. The atmospheric cycling and air-sea exchange of mercury species in the South and equatorial Atlantic Ocean. Deep Sea Res. Part II 46, 957-977.

Lanzillotta, E., Ferrara, R., 2001. Daily trend of dissolved gaseous mercury concentration in coastal seawater of the Mediterranean basin. Chemosphere 45, 935-940.

Lanzillotta, E., Ceccarini, C., Ferrara, R., 2002. Photo-induced formation of dissolved gaseous mercury in coastal and offshore seawater of the Mediterranean basin. Sci. Total Environ. 300, 179-187.

Lanzillotta, E., Ceccarini, C., Ferrara, R., Dini, F., Frontini, F.P., Banchetti, R., 2004 Importance of the biogenic organic matter in photo-formation of dissolved gaseous mercury in a culture of the marine diatom Chaetoceros sp. Sci. Tota Environ. 318, 211-221.

Laurier, F.J.G., Mason, R.P., Gill, G.A., Whalin, L., 2004. Mercury distributions in the North Pacific Ocean-20 years of observations. Mar. Chem. 90, 3-19.

Liss, P.W., Slater, P.G., 1974. Flux of gases across the air-sea interface. Nature 247, $181-184$.

Marumoto, K., Imai, S., 2015. Determination of dissolved gaseous mercury in seawater of Minamata Bay and estimation for mercury exchange across air-sea interface. Mar. Chem. 168, 9-17.

Mason, R.P., Sheu, G.R., 2002. Role of the ocean in the global mercury cycle. Glob. Biogeochem. Cycles 16, 1093. http://dx.doi.org/10.1029/2001GB001440.

Narukawa, M., Sakata, M., Marumoto, K., Asakura, K., 2006. Air-sea exchange of mercury in Tokyo Bay. J. Ocean. 62, 249-257.

Nguyen, H.T., Kim, K.H., Kim, M.Y., Hong, S., Youn, Y.H., Shon, Z.H., Lee, J.S., 2007 Monitoring of atmospheric mercury at a global atmospheric watch (GAW) site on an-Myun Island, Korea. Water Air Soil Pollut. 185, 149-164.

Nguyen, H.T., Kim, M.Y., Kim, K.H., 2010. The influence of long-range transport on atmospheric mercury on Jeju Island,. Korea. Sci. Total Environ. 408, 1295-1307.

Obrist, D., Hallar, A.G., McCubbin, I., Stephens, B.B., Rahn, T., 2008. Atmospheric mercury concentrations at Storm Peak Laboratory in the RockyMountains: evidence for long-range transport from Asia, boundary layer contributions, and plant mercury uptake. Atmos. Environ. 42, 7579-7589.

Pacyna, E.G. Pacyna, J.M., Sundseth, K. Munthe, J., Kindbom, K. Wilson, S., Steenhuisen, F., Maxson, P., 2010. Global emission of mercury to the atmosphere from anthropogenic sources in 2005 and projections to 2020. Atmos. Environ. 44, 2487-2499.

Radke, L.F., Friedli, H.R., Heikes, B.G., 2007. Atmospheric mercury over the NE Pacific during spring 2002: gradients, residence time, upper troposphere lower stratosphere loss, and long-range transport. J. Geophys. Res. 112, D19305. http:// dx.doi.org/10.1029/2005JD005828.

Rolfhus, K.R., Fitzgerald, W.F., 2004. Mechanisms and temporal variability of dissolved gaseous mercury production in coastal seawater. Mar. Chem. 90, 125-136.

Schartup, A.T., Ndu, U., Balcom, P.H., Mason, R.P., Sunderland, E.M., 2015. Contrasting effects of marine and terrestrially derived dissolved organic matter on mercury speciation and bioavailability in seawater. Environ. Sci. Technol. 49, 5965-5972.

Schroeder, W.H., Munthe, J., 1998. Atmospheric mercury-an overview. Atmos. Environ. 32, 809-822.

Selin, N.E., Jacob, D.J., Park, R.J., Yantosca, R.M., Strode, S., Jaeglé, L., Jaffe, D., 2007. Chemical cycling and deposition of atmospheric mercury: global constraints from observations. J. Geophys. Res. 112, D02308. http://dx.doi.org/10.1029/ 2006JD007450.

Sharif, A., Tessier, E., Bouchet, S., Monperrus, M., Pinaly, H., Amouroux, D., 2013. Comparison of different air-water gas exchange models to determine gaseous mercury evasion from different European coastal lagoons and estuaries. Water Air Soil Pollut. 224, 1-16.

Shi, J.B., Liang, L.N., Yuan, C.G., He, B., Jiang, G.B., 2005. Methylmercury and tota mercury in sediments collected from the East China Sea. Bull. Environ. Contam. Toxicol. 74, 980-987.

Soerensen, A.L., Skov, H., Jacob, D.J., Soerensen, B.T., Johnson, M.S., 2010a. Global concentrations of gaseous elemental mercury and reactive gaseous mercury in the marine boundary layer. Environ. Sci. Technol. 44, 7425-7430.

Soerensen, A.L., Sunderland, E.M., Holmes, C.D., Jacob, D.J., Yantosca, R.M., Skov, H., Christensen, J.H., Strode, S.A., Mason, R.P., 2010b. An improved global model fo air-sea exchange of mercury: high concentrations over the North Atlantic Environ. Sci. Technol. 44, 8574-8580.

Soerensen, A.L., Mason, R.P., Balcon, P.H., Sunderland, E.M., 2013. Drivers of surface ocean mercury concentrations and air-sea exchange in the West Atlantic Ocean. Environ. Sci. Technol. 47, 7757-7765.

Soerensen, A.L., Mason, R.P., Balcom, P.H., Jacob, D.J., Zhang, Y., Kuss, J., Sunderland, E.M., 2014. Elemental mercury concentrations and fluxes in the tropical atmosphere and ocean. Environ. Sci. Technol. 48, 11312-11319.

Sprovieri, F., Pirrone, N., Ebinghaus, R., Kock, H., Dommergue, A., 2010. A review of worldwide atmospheric mercury measurements,. Atmos. Chem. Phys. 10, 8245-8265.

Strode, S.A., Jaeglé, L., Selin, N.E., Jacob, D.J., Park, R.J., Yantosca, R.M., Mason, R.P., Slemr, F., 2007. Air-sea exchange in the global mercury cycle. Glob. Biogeochem. Cycles 21, GB1017. http://dx.doi.org/10.1029/2006GB002766.

Strode, S., Jaeglé, L., Emerson, S., 2010. Vertical transport of anthropogenic mercury in the ocean. Glob. Biogeochem. Cycles 24, GB4014. http://dx.doi.org/10.1029/ 2009GB003728.

Su, S., Xiao, R., Mi, X., Xu, X., Zhang, Z., Wu, J., 2013. Spatial determinants of hazardous chemicals in surface water of Qiantang River, China. Ecol. Indic. 24, 375-381.

Sunderland, E.M., Mason, R.P., 2007. Human impacts on open ocean mercury concentrations. Glob. Biogeochem. Cycles 21, GB4022. http://dx.doi.org/10.1029/ 2006GB002876.

Travnikov, O., 2005. Contribution of the intercontinental atmospheric transport to mercury pollution in the Northern Hemisphere. Atmos. Environ 39, 7541-7548.

Tseng, C.M., Liu, C.S., Lamborg, C.H., 2012. Seasonal changes in gaseous elemental mercury in relation to monsoon cycling over the Northern South China Sea. Atmos. Chem. Phys. 12, 7341-7350.

Tseng, C.M., Lamborg, C.H., Hsu, S.C., 2013. A unique seasonal pattern in dissolved elemental mercury in the South China Sea, a tropical and monsoon-dominated marginal sea. Geophys. Res. Lett. 40, 167-172.

UNEP, 2013. Global Mercury Assessment 2013: Sources, Emissions, Releases and Environmental Transport. UNEP Chemicals Branch, Geneva, Switzerland.

USEPA, 2002. Method 1631, Revision E: Mercury in Water by Oxidation, Purge and Trap, and Cold Vapor Atomic Fluorescence Spectrometry (EPA-821-R-02-019). United States Environment Protection Agency, Washington, DC.

Wang, Y.Q., Zhang, X.Y., Draxler, R.R., 2009. TrajStat: GIS-based software that uses various trajectory statistical analysis methods to identify potential sources from long-term air pollution measurement data. Environ. Modell. Softw. 28, 938-939.

Wang, X., Qiao, F., Lu, J., Gong, F., 2011. The turbidity maxima of the northern Jiangsu shoal-water in the Yellow Sea, China. Estuar. Coast. Shelf Sci. 93, 202-211.

Wang, C., Wang, Z., Ci, Z., Zhang, X., Tang, X., 2016a. Spatial-temporal distributions of gaseous element mercury and particulate mercury in the Asian marine boundary layer. Atmos. Environ. 126, 107-116.

Wang, C., Ci, Z., Wang, Z., Zhang, X., Guo, J., 2016b. Speciated atmospheric mercury in the marine boundary layer of the Bohai Sea and Yellow Sea. Atmos. Environ. 131, 360-370.

Wängberg, I., Schmolke, S., Schager, P., Munthe, J., Ebinghaus, R., Iverfeldt, Å., 2001. Estimates of air-sea exchange of mercury in the Baltic Sea. Atmos. Environ. 35, 5477-5484.

Wanninkhof, R., 1992. Relationship between wind speed and gas exchange over the ocean. J. Geophys. Res. 97, 7373-7382.

Wu, Y., Wang, W., 2014. Intracellular speciation and transformation of inorganic mercury in marine phytoplankton. Aquat. Toxicol. 148, 122-129.

Xiu, G., Cai, J., Zhang, W., Zhang, D., Büeler, A., Lee, S., Shen, Y., Xu, L., Hunag, X. Zhang, P., 2009. Speciated mercury in size-fractionated particles in Shanghai ambient air. Atmos. Environ. 43, 3145-3154.

Xu, L., Chen, J., Niu, Z., Yin, L., Chen, Y., 2013. Characterization of mercury in atmospheric particulate matter in the southeast coastal cities of China. Atmos. Pollut. Res. 4, 454-461.

Xu, L., Chen, J., Yang, L., Niu, Z., Tong, L., Yin, L., Chen, Y., 2015. Characteristics and sources of atmospheric mercury speciation in a coastal city, Xiamen, China. Chemosphere 119, 530-539.

Zhang, H., Li, S., 2010. Effects of physical and biochemical processes on the dissolved oxygen budget for the Pearl River Estuary during summer. J. Mar. Syst. 79, 65-88.

Zhang, W., Yang, X., Ma, Y., Zhu, H., Wang, S., 2011. Continuous flow electrolytic cold vapor generation atomic fluorescence spectrometric determination of $\mathrm{Hg}$ in water samples. Microchem. J. 97, 201-206.

Zhang, L., Wang, S., Wang, L., Wu, Y., Duan, L., Wu, O., Wang, F., Yang, M., Yang, H. Hao, J., Liu, X., 2015a. Updated emission inventories for speciated atmospheric mercury from anthropogenic sources in China. Environ. Sci. Technol. 49, 3185-3194.

Zhang, Y., Jacob, D.J., Dutkiewicz, S., Amos, H.M., Long, M.S., Sunderland, E.M., 2015b. Biogeochemical drivers of the fate of riverine mercury discharged to the global and Arctic oceans. Global Biogeochem. Cycles 29, 854-864. http://dx.doi. org/10.1002/2015GB005124.

Zhu, J., Wang, T., Talbot, R., Mao, H., Yang, X., Fu, C., Sun, J., Zhuang, B., Li, S., Han, Y., Xie, M., 2014. Characteristics of atmospheric mercury deposition and sizefractionated particulate mercury in urban Nanjing China. Atmos. Chem. Phys. $14,2233-2244$. 